\title{
US to attend or stay away?
}

\section{New Orleans}

Attendance at the 1986 World Archaeology Congress at Southampton, England, has become a "moral litmus test" for US archaeologists. But there was no consensus among potential participants at the meeting here last month of the Society for American Archeology (SAA).

The congress, planned over several years with special attention to the participation of scientists from developing countries, has been controversial ever since the British organizing committee sent letters of "disinvitation" to South African and Namibian scientists. In the aftermath, the international parent body, the International Union of Prehistoric and Protohistoric Sciences (IUPPS), withdrew

its recognition of the Southampton meeting; a conference to be held in Mainz, West Germany, in September 1987 is now recognized as the official 11th World Archaeology Congress (see Nature 320, 3; 1986).

Opinion at New Orleans seems to have been that it is for scientists individually to decide how to balance the principle of a stand against apartheid and that of free international exchange between scientists.

Thus one would-be participant said that he wanted nothing to do with a meeting that would exclude such noted scientists and opponents of apartheid as Professor Phillip Tobias (University of the Witwatersrand), but that "I don't go along

\section{Biotechnology}

\section{DNA fingerprints go commercial}

By early next year, and for something like $£ 250$, it will be possible to obtain a DNA fingerprint from a blood or tissue sample sent to a testing centre in Britain. The initial demand is expected to be for paternity testing, but the test has already proved invaluable in proving relationships that are doubted by immigration authorities and has considerable potential in forensic testing too.

The centre is to be operated by the diagnostics group of Imperial Chemical Industries (ICI), the British chemical and pharmaceutical giant, which is in an advanced stage of negotiation with the Lister Institute for the exclusive rights to a test devised by Dr Alec Jeffries of the University of Leicester. Royalties from the tests, which are likely to be substantial, will be shared by the University of Leicester, Dr Jeffries and the Lister Institute, of which he is a research fellow.

It requires considerable expertise to carry out the test, which types individuals in terms of a set of highly variable DNA sequences on human chromosomes. At the heart of the test is a process of hybridization between the individual's DNA and radioactive DNA probes. Before the hybridization can be carried out, however, the DNA has to be extracted and cut by enzymes into fragments which are separated according to size. Even after hybridization, it is not a simple matter to interpret the "result", a series of radioisotopic bands on a gel.

Although such techniques are routine in molecular genetics laboratories, they are much too demanding for any routine diagnostic laboratory. That is why the DNA fingerprinting test will not be marketed as a kit but offered as a service. (There is one commercial kit based on
DNA hybridization which is used for the detection of salmonella, and its manufacturers, Integrated Genetics, plan others. But none of these tests will require other than crude sample preparations and they only detect the presence or absence of a DNA sequence that identifies the organism.)

Demand for the test seems certain to be considerable, with estimates that many thousands of immigration disputes worldwide could be settled each year. Dr Jeffries has been able to cope with only a few per cent of the requests that he has received in the wake of the initial publications that illustrated the potential of DNA fingerprinting (Nature 314, 67; 316, $76 ; \mathbf{3 1 7}, 818$ and $\mathbf{3 1 8}, 577$ (1985)).

Forensic testing is likely to be more problematic because of the need for prosecution and defence to have recourse to independent tests. There is therefore considerable uneasiness about there being only one centre to which samples can be sent. One solution in Britain would be for the Home Office Forensic Science Service, which has been evaluating the test, to carry out its own DNA fingerprinting, presumably for the police, while the defence made use of the ICI centre. Another solution would be to allow separate scientists, acting for the two sides, to have independent access to a single facility, as they sometimes do now in forensic science laboratories.

Further demand for testing may come from the armed forces. In the United States, at least, there have already been discreet enquiries about the possibility of having all military personnel DNA fingerprinted to make it possible to identify from tissue fragments the victims of air disasters or bombings. Peter Newmark with some colleagues' wish to ostracize those who may attend"

On the other hand, Thomas Patterson (Temple University), a co-founder of Archaeologists Against Apartheid, urged colleagues to attend the Southampton congress to avoid giving the impression that US archaeologists, "consciously or unconsciously", are in favour of apartheid. According to Ian Hodder (University of Cambridge), some 22 per cent of registrants from the United States have already cancelled.

The large number of participants from developing countries expected at Southampton adds another side to the question. Hodder says that many of them would either be prevented by their governments from attending, or would abstain on their own if South Africans were to be present.

Some at the SAA meeting raised the further question of whether an international congress is possible at all. "What guarantee is there that the same problems will not recur in Mainz?", one archaeologist asked. Hodder says that antiapartheid groups in West Germany are mobilizing to protest at that meeting.

Meanwhile, in Berkeley, California, a symposium held in mid-April to honour anthropologist J. Desmond Clark upon his retirement, with the participation of several scholars from South Africa, passed without incident, because the existence of the symposium was not made known to anti-apartheid groups there (see Nature 320, 562; 1986).

One project scheduled for discussion at Southampton is the establishment of a truly international body, to correct what is generally conceded to be a European bias in the present make-up of the international union. A more broadly based coalition, it is hoped, could better ensure the free assembly of its members.

James Sacket (University of California, Los Angeles) urged that the United States should bring more weight to bear in future actions of IUPPS, where its role is small although it contributes a large proportion of the world's practising archaeologists. He suggested that one step towards the greater internationalization desired by all would be to hold the 12 th World Archaeology Congress, scheduled for 1991, in the United States.

A member of the IUPPS executive committee, Sacket had made several at tempts to reconcile the position of the British national committee with the requirements of IUPPS, proposing for example that participants should have the option of registering simply as individuals and not in the name of their country, but was unable to effect a compromise. "I was told that "We do not want interference from the great powers'", he said. Thus, at this point, the future role of the United States in the international union seems problematic.

Sandra Ackerman 